\title{
In vitro cultures of carnivorous plants from the Drosera and Dionaea genus for the production of biologically active secondary metabolites
}

\author{
Rafae Banasiuk, Anna KawiaK, Aleksandra Królicka* \\ Laboratory of Plant Protection and Biotechnology, Department of Biotechnology, \\ Intercollegiate Faculty of Biotechnology, University of Gdansk \& Medical University of Gdansk, Gdańsk, Poland \\ *Corresponding author: krolicka@biotech.ug.gda.pl
}

\begin{abstract}
Carnivorous plants belong to endangered species. Due to agricultural development, natural populations of these plants are diminishing. The herbal and ornamental value of these species has also led to their over-collection. The Droseragenus is a natural source of pharmacologically important compounds (e.g. naphthoquinones, flavonoids, anthocyanins, phenolic compounds) used as substrates in the production of pharmaceuticals. Droserae herba has been in use as an expectorant, diuretic and antispasmodic agent. In recent years, the bacteriostatic and antitumour activity of Drosera extracts has been reported. Carnivorous plants have become an important ornamental element in botanical garden collections. This fact, as well as the low propagation rate in their natural environment, is the reason for the in vitro propagation of carnivorous plants. From a single plant cultivated in vitro many genetically identical clonal lines can be obtained through vegetative propagation. This technique allows for the increase in the propagation rate of valuable plant material. Additionally, the use of biotic and abiotic elicitors increases the synthesis of pharmacologically active compounds (bactericidal, bacteriostatic activity and cytotoxic activity). Elicitors play a significant role in the production of secondary metabolites. They induce defense responses in plants, which leads to the accumulation of secondary metabolites. In some cases, compounds not synthesized normally by plants in their natural environment are produced upon elicitation. Elicitors induce the biosynthesis of enzymes which take part in the production of secondary metabolites.
\end{abstract}

Key words: antimicrobial activity, antioxidant, cytotoxic activity, flavonoids, micropropagation, naphthoquinones

\section{Introduction}

Carnivorous plants are a phenomenon in the plant kingdom as they obtain their nutrients from captured prey. Many early botanists were reluctant to accept the fact that plants could be capable of trapping and digesting insects. The first evidence of the carnivorous syndrome was provided by Darwin in 1875 his "Insectivorous plants". The term insectivorous is not quite accurate, as the prey of these plants does not strictly consist of insects and includes larger invertebrates, or even vertebrates.

The term "carnivorous" is assigned to plants which can digest prey by means of enzyme secretion. This does not include plants that rely on the bacterial activity for digestion. Development of carnivory in plants is associated with the environment that these plants inhabit. It is a means of survival in nutrient-poor soils. The carni- vorous plants are a very diverse group, with an estimated 600 species identified in both monocotyledons and dicotyledons. Schauler divided these plants into 6 orders comprising 20 genera (Juniper et al., 1989).

Droseracae spp. are widely used in folk medicine. They have been reported to work in cases of pulmonary diseases and coughs (Didry et al., 1998). The most popular form of their usage was topical or administered per $o s$ in the form of a tincture (Caniato et al., 1989). It is now known that they owe their properties to two groups of compounds - naphthoquinones and flavonoids. A broad variety of secondary metabolites are used in the pharmaceutical, cosmetic and food industry. A majority of these compounds are still obtained from natural habitats that are becoming increasingly scarce. This is the result of frequent plant harvesting and the growing deterioration of natural habitats. A rapid decline in novel 
drug sources has led to an increased interest regarding compounds that are derived using in vitro methods, an approach which minimises the influence of pests, diseases, climate and the dependence on geographical location (Burbidge, 1994).

\section{Significance of carnivorous plants in phytotherapy}

An estimated 50000 biologically active compounds are derived from plants. They are termed secondary metabolites, as they are not involved in the basic metabolism of plants but are developed as a result of specialised metabolic pathways (Kohlmünzer, 2003). Plants have been a source of pharmaceutical compounds since the $7^{\text {th }}$ century B.C. Phytotherapy expanded in Europe in the $16^{\text {th }}$ and $17^{\text {th }}$ centuries. During the second half of the $19^{\text {th }}$ century, the interest in phytotherapy decreased and herbs were replaced with synthetic pharmaceuticals. Yet, in the age of chemotherapy a new threat has appeared. The number of drug side effects has increased; moreover, not all synthetic drugs are as effective as the natural ones. This has led to an increased interest in phytopharmaceuticals. Medicinal plants are again becoming the subject of interest for many scientists and medical doctors.

Droserae herba is a source of cyanogens, flavonoids (quercetin, kaempferol), naphthoquinones (plumbagin, ramentaceone) (Table 1), proteolytic enzymes, anthocyanins, phenolic compounds, organic acids. In the recent years, phenolic compounds from in vitro cultured plants have been examined (Budzianowski, 1996; Didry et al., 1998). Drosera extracts were reported to contain 1,4-naphthoquinones, ellagic acid and its derivatives. Among the naphthoquinones which have been found to be pharmaceutically active compounds, plumbagin and 7-methyljuglone predominate. These compounds are present in a free form and in the form of glucosides: 7-methyljuglone 4-O-glucoside (rossoliside) and hydroplumbagin 4-O-glucoside (Pich and Schubert, 1993). Preparations used in phytotherapy that contain Drosera extracts include: Drosetux (Dolisos; Dagomed - Pharma), Thymipin (Zyma), Makatussin Forte (Makara), Drosera Complexe Nr 64 (Lehning) and Malia (Dagomed - Pharma).

\section{Naphthoquinones}

Naphthoquinones are naphthalene derivatives. The naphthoquinone backbone can be substituted either at the $\mathrm{C}_{1}$ and $\mathrm{C}_{4}$ or $\mathrm{C}_{1} \mathrm{C}_{2}$ carbons giving 1,4 or 1,2 naphthoquinones, respectively. Apart from monomeric structures, dimeric and trimeric structures are also known. These compounds possess color that can be seen in the visible light spectrum that varies from yellow to brown. Almost all naphthoquinones are soluble in benzene, chloroform, acetone and alcohols.

Naphthoquinones such as plumbagin, ramentaceone and lapachol possess cytotoxic properties. Cell death induced by these compounds was observed, among others, in the following cell lines: HEPA-3B (Kuo et al., 1997), HL-60 (Kawiak et al., 2007), U937, HeLa, MCF-7, HCT-116 (Kawiak et al., 2011), SKBR3 and BT474 (Kawiak et al., $2012 \mathrm{a} ; 2012 \mathrm{~b}$ ). Their mechanism of action is based on a few mechanisms such as DNA intercalation, reactive oxygen species formation, prevention of thymidine addition to DNA and retardation of orotic acid synthesis (Babula et al., 2009). Research shows that naphthoquinones induce cell death in cancer cell lines through triggered apoptotic pathways. Plumbagin has been reported to selectively induce apoptosis in cancer cells (Ahmad et al., 2008). Moreover, in vivo studies showed that plumbagin reduces the size of tumors by $70 \%$ in nude mice implanted with tumor cell xenografts with no observed toxic side effects (Kuo et al., 2006).

Naphthoquinones also possess bactericidal and fungicidal properties. Didry et al. (1998) reported that chloroform extracts of the aerial parts of $D$. peltata present a broad range of activity against oral bacteria (Streptococcus, Prevotella). This activity is ascribed to plumbagin which is the main active compound of the extract. Plumbagin has also been noted to be effective against antibiotic resistant bacteria (bacteria grown in the presence of plumbagin did not develop an immunity to streptomycin and rifampicin) (Durga et al., 1990). Krolicka et al. (2010) determined the minimal bactericidal concentration $(\mathrm{MBC})$ values using extracts from $D$. capensis var. Broadleaf and D. muscipula against the following human pathogens: Enterococcus faecalis, Staphylococcus aureus, Klebsiella pneumoniae and Pseudomonas aeruginosa, both antibiotic susceptible and resistant strains. The broadest range of antimicrobial activity and the strongest antibacterial effects were observed in the methanol extract obtained from $D$. muscipula grown on the media with depleted nitrogen content. This extract was active against all the bacterial species tested (MBC $=25-75 \mathrm{mg}$ fresh weight $/ \mathrm{ml})$. Ferreira et al. (2004) 
Table 1. List of basic naphtoquinones with their chemical properties

\begin{tabular}{|c|c|c|c|c|}
\hline Substituent & Systematic name & $\begin{array}{l}\text { Common } \\
\text { name }\end{array}$ & $\begin{array}{c}\text { Melting point } \\
{\left[{ }^{\circ} \mathrm{C}\right]}\end{array}$ & $\begin{array}{c}\text { Molecular } \\
\text { weight }\end{array}$ \\
\hline & 1,4-naphthoquinone & & $119-122$ & 158.15 \\
\hline $\mathrm{R} 1=\mathrm{CH}_{3}, \mathrm{R}_{3}=\mathrm{OH}$ & $\begin{array}{l}\text { 5-hydroxy-2-methy-1,4- } \\
\text { naphthoquinone }\end{array}$ & plumbagin & $78-79$ & 188.18 \\
\hline $\mathrm{R} 3=\mathrm{OH}$ & 5-hydroxy-1,4-naphthoquinone & Juglone & 155 & 174.14 \\
\hline $\mathrm{R} 1=\mathrm{CH}_{3}$ & 2-methyl-1,4-naphthoquinone & menadion & $105-107$ & 172.18 \\
\hline $\mathrm{R} 3, \mathrm{R} 6=\mathrm{OH}$ & 5,8-dihydroxy-1,4-naphthoquinone & naphtazalin & 237 & 190.16 \\
\hline $\mathrm{R} 1, \mathrm{R} 3, \mathrm{R} 5=\mathrm{OH}$ & 2,5,7-trihydroxy-1,4-naphthoquinone & Flaviolin & $164-168.5$ & 206.17 \\
\hline $\begin{array}{l}\mathrm{R} 1=\mathrm{CHOHCH}_{2} \mathrm{CH}=\mathrm{C}\left(\mathrm{CH}_{3}\right)_{2} \\
\mathrm{R} 3, \mathrm{R} 6=\mathrm{OH}\end{array}$ & $\begin{array}{l}\text { 5,8-dihydroxy-2-(1-hydroxy-4-methylpent- } \\
\text { 3-enyl)-1,4-naphthoquinone }\end{array}$ & Shikonin & $145-146$ & 288.30 \\
\hline $\begin{array}{l}\mathrm{R} 1=\mathrm{OH} \\
\mathrm{R} 2=\mathrm{CH}_{2} \mathrm{CH}=\mathrm{C}\left(\mathrm{CH}_{3}\right)_{2}\end{array}$ & $\begin{array}{l}\text { 2-hydroxy-3-(3-methyl-but-2-enyl)- } \\
\text { 1,4-naphthoquinone }\end{array}$ & Lapachol & $141-143$ & 242.27 \\
\hline
\end{tabular}

tested native Brazilian Drosera species against $S$. aureus, Enterococus faecium, $K$. pneumonie and Candida albicans. Three types of sundew extracts - methanolic, hexane and ethyl acetate were tested for each microorganism. Growth of the microorganisms varied depending on the Drosera species used and the type of extract. These data clearly show that quinones are not the only microbiologically active compounds present in Droseracae. Previous studies in metabolite levels in in vitro cultures of Drosera spp. have shown a higher level of plumbagin for in vivo grown plants (Crouch et al., 1990). The reason for this phenomenon is unknown and may be caused by a missing environmental factor. The level of quinones in plants is directly linked to the growth medium. According to the research by Ziaratnia et al. (2009), for the production of 7-methyljuglone Murashige and Skoog (MS), half-strength MS or Gamborg $\mathrm{B}_{5}$ media are advised. The worst result for the tested media was presented in plants grown on $1 / 3$ strength MS medium.

\section{Flavonoids}

Flavonoids are compounds that are specific for flowering plants. They are most commonly found dissolved in cell sap. They play the role of a yellow pigment, mostly in flowers and leaves. Flavonoids are one of the main biologically active compounds in plant tissues. Over 4000 plant derived flavonoids have been isolated and identified (Williams and Grayer, 2004). The precursor for all known flavonoids is chalcone and its derivatives ( 2 '-hydroxychalcone, trihydroxychalcone). The basic backbone structure for this group of compounds has 15 carbon atoms and can be characterized as $\mathrm{C}_{6}-\mathrm{C}_{3}-\mathrm{C}_{6}$ (two aromatic rings and a 3 carbon bridge created through the shikimic acid pathway). In most cases, the phenyl ring with the bridge atoms form a 1,4-benzopyrone-like structure so flavonoids may be called chromone derivatives.

Flavonoids play many important roles in plant biochemistry. Their basic function is to protect the cells from oxidative stress due to their strong antioxidant properties and ability to scavenge free radicals (Lin et al., 2002; Vladimirov et al., 2009). The most interesting function of this group of compounds is their antimicrobial properties. Flavonoids, like quercetin and myricetin, help fight possible bacterial infections (Cushnie and Lamb, 2005). These two properties are mostly used by the pharmaceutical and cosmetic industry (Brand-Garnys et al., 2007). Other functions include helping tissues to cope with heavy metal poisoning (chelating ability mainly $\mathrm{Fe}^{3+}$ and $\mathrm{Cu}^{2+}$ ) (Fernandez et al., 2002; Mira et 
al., 2002), repelling herbivores and insects (Wang et al., 2012), pollination readiness indicator or even nitrogenfixing bacteria attractant (it is known that legumes use flavonoids as signal compounds for the Rhizobium bacteria) (Eckardt, 2006).

Flavonoids, because of their structural diversity, possess many proven pharmacological properties such as anti-cancer activity. Apart from the ability to wipe out reactive singlet oxygen form, they also have the ability to alter the key mechanisms responsible for carcinoma development as they do in CYP1A and CYP1B1 blockage that is responsible for forming active forms of carcinogens such as polycyclic aromatic hydrocarbons (Doostdar et al., 2000). Apart from these properties, it was proven that flavonoids present in tea enhance the enzymatic activities responsible for organism detoxification (McKay and Blumberg, 2002). Another valued property is their anti-inflammatory activity which is correlated with the blockage of the arachidonic acid transformation pathway (Ferrandiz and Alcaraz, 1991). Flavonoids are known inhibitors of many enzymes including thyroperoxidase deiodinases (Ferreira et al., 2002), and hyaluronidases (Pithayanukul et al., 2010). Because of the interactions with the cardiovascular system, some flavonoids are used as varice, extravasation and arteriosclerosis prevention agents (Vasanthi et al., 2012). They also work as antihistamines (Yamamura et al., 1998) and mimic human estrogen properties (Miksicek, 1993).

Studies by Iwashita et al. (2000) showed that quercetin that is present in Drosera species induces apoptosis in B16 Melanoma 4A5 cells. Paper et al. (2005) performed a HEX-CAM (hen's eggs test - chorioallantoic membrane) assay to examine the anti-inflammatory activity of $D$. rotundifolia and D. madagascariensis extracts that is ascribed to their flavonoid content. Ethanol extracts proved more effective than hydrocortisone. In addition, it has been demonstrated that methanol extract from Drosera aliciae containing quercitin and myricetin has strong antioxidant activity (Krolicka et al., 2009).

\section{Secondary metabolites extraction from carnivorous plants}

The main solvents used for the extraction of secondary metabolites in carnivorous plants are methanol and chloroform. Methanol gives a high overall extraction yield whereas chloroform is more selective towards naphthoquinones. The first extraction step usually involves maceration with or without the use of liquid nitrogen for better tissue penetration. Dry and fresh plant material is used for the process but the secondary metabolite yields for fresh material are much higher (Marczak et al., 2005). The most commonly used techniques are simple maceration, ultrasound enhanced extraction and Soxhlet extraction. Kołodziejski (2010) compared different extraction methods, namely Soxhlet extraction, homogenization, ultrasound extraction, maceration and microwave enhanced extraction with the use of methanol as the main solvent. The highest yields of naphthoquinones and flavonoids were obtained by using long term maceration and ultrasonic disintegration. Grevenstuk et al. (2012) presented a different approach by using supercritical $\mathrm{CO}_{2}$ extraction and n-hexane that are more selective towards naphthoquinones. Their study has proven that ultrasonic assisted extraction gives the highest plumbagin yield surpassing supercritical liquid extraction, probably because of the complexity of the sample matrix. In the work presented by Marczak et al. (2005), methanol and chloroform were tested as solvents for obtaining quinones. Chloroform was shown to be a better solvent but it was also stated that some compounds extract better from the plant matrix with the use of methanol. Kämäräinen et al. (2003) used toluene as the extraction solvent.

\section{In vitro propagation of carnivorous plants}

Carnivorous plants are a phenomenon in the plant kingdom and are valued as ornamental plants. They capture their prey by means of specialized trapping devices, which is an additional way to obtain proteins - a source of nitrogen that is essential for the proper development of all organisms (Williams, 1982). Carnivorous plants have become an important ornamental element in botanical garden collections. This fact as well as the low propagation rate of these plants in their natural environment is the reason for the in vitro propagation of carnivorous plants.

From a single plant cultivated in vitro many genetically identical clonal lines can be obtained through vegetative propagation. This technique allows for an increase in the propagation rate of valuable plant material. Micropropagation can be a means of multiplication of ornamental plants (Orchidaceae, Rosaceae), rare and end- 
angered species (Orchidaceae, Rubus) as well as plants that are a source of secondary metabolites (Lithospermum erythrorhizon, Panax ginseng, Echinacea purpurea, Curcuma longa).

Work regarding in vitro cultures of carnivorous plants has been carried out in different laboratories in Poland. The first research carried out in the Botanical Garden in Wrocław involved species such as: Dionaea muscipula (Kukułczanka et al. 1989), Drosophyllum lusitanicum (Kukułczanka and Cząstka, 1991), Drosera intermedia L., Drosera rotundifolia L., Drosera spathulata L. (Kukułczanka et al., 1991) and Drosera bredifolia Pursh (Kukułczanka and Cząstka, 1987). These species were cultivated on Reinert and Mohr (RM) and Murashige and Skoog (MS) media. Janssens (1986) reported the micropropagation of Drosera regia on the MS medium with a modified vitamin composition. The micropropagation of Dionaea muscipula has frequently been reported (Garnett 1982; Bruce et al., 1982; Minocha, 1985; Królicka et al., 2008).

Research carried out in the Laboratory of Plant Protection and Biotechnology of the Intercollegiate Faculty of Biotechnology in Gdańsk, Poland, has allowed to define the optimal media and in vitro culture conditions for the following carnivorous species (Fig. 1): Drosera ramentaceae, Drosera anglica, Drosera binata, Drosera cuneifolia, Dionaea muscipula, Drosera capensis (Kawiak, 2002; Kawiak et al., 2003; Krolicka et al., 2008), Drosera aliciae (Krolicka et al., 2008, Kawiak et al., 2011), Drosera adelae (Kawiak et al., 2002) and Drosera gigantea (Taraszkiewicz et al., 2012). Various solidified and liquid media were tested: MS and half-strength MS, RM, Lindemann, Vacin and Went and Fast (Fig. 2). The media were supplemented with various concentrations of growth regulators including auxins: 2,4 dichlorophenoxyacetic acid (2,4-D), naphthylacetic acid (NAA), indoleacetic acid (IAA) and cytokinins: kinetin (KIN), 6-benzylaminopurine (BAP), zeatin $(Z)$ and gibberellins $\left(\mathrm{GA}_{3}\right)$. The optimal media for the in vitro propagation of plants from the Drosera and Dionaea genus proved to be the 1/2 MS and RM media. In order to obtain a high reproduction rate, leaves were cut into explants and placed on media supplemented with growth regulators. After a period of 6-8 weeks, an average of 3 to 12 plants were obtained from one explant. It was estimated that 100 to 300 plants can be obtained within a period of one year. After 16-20 weeks the following proliferation rates were obtained for the particular species - Drosera anglica (1:8), Drosera binata (1:12) and Drosera cuneifolia (1:6) (Kawiak, 2002; Kawiak et al., 2003). Figure 1 demonstrates the growth obtained in in vitro cultures of $D$. anglica, $D$. binata and D. cuneifolia on different media (Kawiak, 2002).

As can be seen from the data presented above, it is impossible to choose an ideal medium for all Drosera species. If one medium ought to be chosen in accordance to this research then half-strength MS medium would provide the best overall results. In a study by Jang et al. (2003), shoot proliferation depending on different concentrations of macroelements in the MS medium was tested. The best results were obtained for $1 / 3$ strength medium and the worst for $1 / 9$ strength medium. According to the study by Grevenstuk et al. (2010), the best growth medium for $D$. intermedia was found to be $1 / 4$ MS. Also, in the same study, it was shown that an addition of kinetin does not enhance plant proliferation. A similar observation was made by Jayaram and Prasad (2005), who found that high concentrations of cytokinins retard the growth of Drosera indica and Drosera burmanii. In the paper by Hook (2001), the difference in growth on solid and liquid media was tested. D. muscipula failed to grow in the liquid medium whereas Droserasp. depicted good growth on either of the tested media. Moreover, $\mathrm{pH}$ of the growth medium plays a key role. In the study presented above, a $\mathrm{pH}$ of 5.5 was used. In previously published studies, the optimal $\mathrm{pH}$ ranged from 5.5 to 5.8. Jayaram and Prasad (2006) stated that $D$. indica survives in a broad range of $\mathrm{pH}$ but the $\mathrm{pH}$ optimum for rooting is 5.7 .

\section{Elicitation of secondary metabolites}

Elicitors play a significant role in the production of secondary metabolites (Verpoorte et al., 1999). They induce defense responses in plants, which leads to the accumulation of secondary metabolites. In some cases, compounds not synthesized normally by plants in their natural environment are produced upon elicitation. Elicitors induce the biosynthesis of enzymes which take part in the production of secondary metabolites (Hahlbrock et al., 1981; Hilton and Rhodes, 1993; Burbidge, 1994).

It was proven that carnivorous plants are susceptible to in vitro elicitation. Because of this phenomenon, it is possible to enhance the production of valuable naphthoquinones (Królicka et al., 2008). Secondary metabolites 


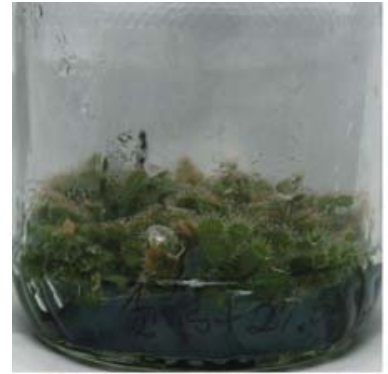

Drosera ramentaceae

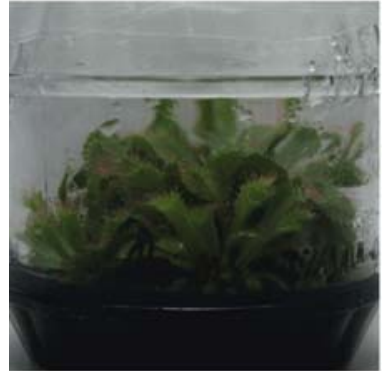

Drosera aliciae

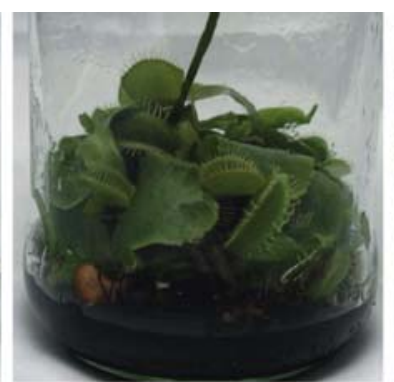

Dionaea mucipula

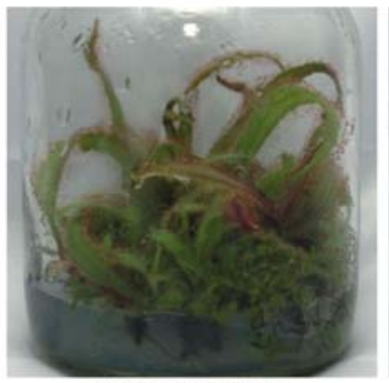

Drosera adelae

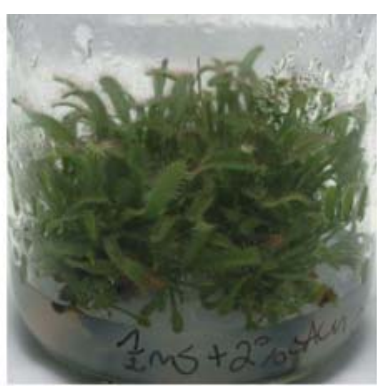

Drosera capensis var Broadleaf

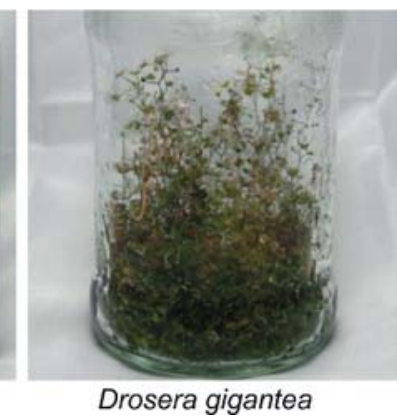

Fig. 1. Collection of carnivorous plants at the Laboratory of Plant Protection and Biotechnology, Intercollegiate Faculty of Biotechnology, UG \& MUG

are produced in plant tissue as a result of plant-pathogen interaction. This is an infection prevention mechanism. The addition of a part of the pathogen cellular wall induces a defensive response and, as a result, the naphthoquinone synthesis occurs (Juniper et al. 1989). Putalun et al. (2010) studied the influence of methyl jasmonate, yeast extract and chitosan. In their study, the yeast extract was found to enhance the production of plumbagin in the roots of $D$. burmaniiby 3.5 -fold when compared to the control plants. Krolicka et al. (2008) demonstrated that using the following elicitors: autoclaved Agrobacterium rhizogenes suspension, crude Verticillium dahliae elicitor, jasmonic acid or lower nitrogen levels, the production of naphthoquinones, ramentaceone and plumbagin, was increased in in vitro grown Drosera capensis var. Broadleaf and D. muscipula cultures. Moreover, L-phenylalanine and trans-cinnamic acid (precursors of shikimate pathway) were used in order to increase the production of flavonoids (quercetin and myricetin).

Another method that is used to increase the level of secondary metabolites using in vitro cultures of carnivorous plants is plant transformation with the use of Agrobacterium rhizogenes. It is a gram negative, rod-shaped, aerobic bacterium belonging to the Agrobacterium (Rhizobiaceae) genus. The virulence of this bacterium is caused by the presence of the Ri plasmid with a T-DNA (transferred DNA) fragment which possesses oncogenes that are transferred to plant cells during the infection process (Singleton, 1999). In literature, there is only one report regarding the carnivorous plant transformation with $A$. rhizogenes (Królicka et al., 2010). Hirsikorpi et al. (2002) have developed a transformation method for $D$. rotundifolia using a modified strain of $A$. tumefaciens obtaining $17 \%$ efficiency of the process. The problems with obtaining carnivorous plant hairy root cultures is that not all plants are equally susceptible to transformation (Porter, 1991). The studied Drosera sp. possesses many antibacterial secondary metabolites that probably also exert their activity against Agrobacterium (Królicka et al., 2010).

\section{Conclusion}

Carnivorous plants are a valued source of secondary metabolites. Studies on the biochemical properties of their compounds are still in progress which contribute new data every year. Because of their overharvesting, the Drosera species are considered endangered. This has warranted the development of standardized in vitro propagation methods for their preservation. These studies have provided the means to continue research on 


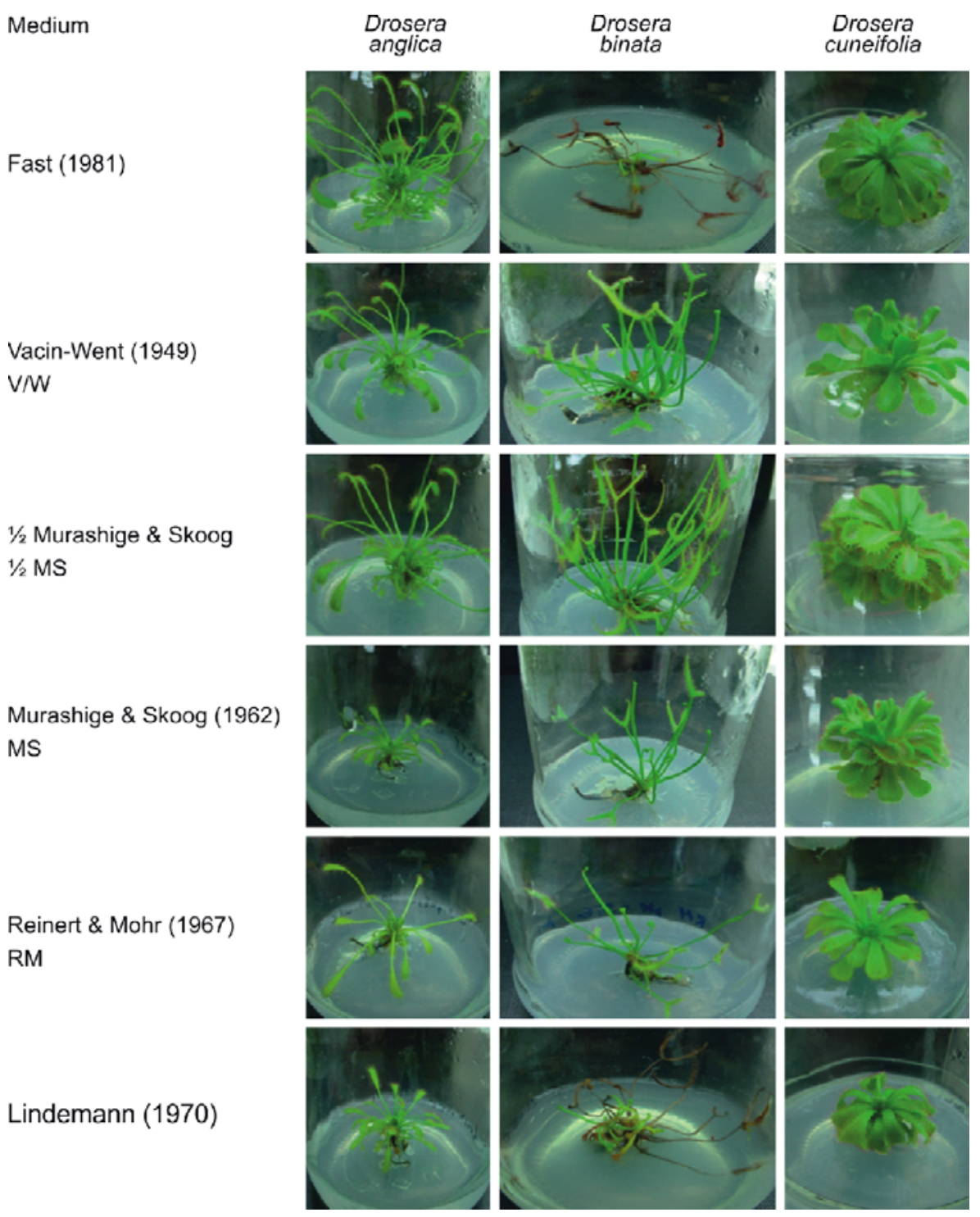

Fig. 2. Growth of Drosera anglica, Drosera binata and Drosera cuneifolia depending on the type of growth media used

these plants. Moreover, in vitro propagation methods offer the means to increase the level of secondary metabolites either through elicitation or genetic modifications.

\section{Acknowledgments}

This work was supported by grant of the Ministry of Science and Higher Education no. 3021/B/P01/2009/36.

\section{References}

Ahmad A., Banerjee S., Wang Z., Kong D., Sarkar F.H. (2008) Plumbagin-induced apoptosis of human breast cancer cells is mediated by inactivation of NF-kappaB and Bcl-2. J. Cell. Biochem. 105(6): 1461-1471.

Babula P., Adam V., Havel L., Kizek R. (2009) Noteworthy secondary metabolites naphthoquinones - their occurrence, pharmacological properties and analysis. Curr. Pharmaceut. Anal. 5(1): 47-68.

Brand-Garnys E.E., Denzer H., Meijer H., Brand H.M. (2007) Flavonoids: A review for cosmetic application. part two. J. App. Cosmetol. 25(4): 145-159.

Bruce J., Philip T., Earlene A. (1982) Tissue culture of single rhizome explants of Dionaea muscipula for rapid asexual propagation. J. Amer. Soc. Hort. Sci. 107: 305-310.

Budzianowski J. (1996) Naphthohydroquinone glucosides of Drosera rotundifolia and $D$. intermedia from in vitro cultures. Phytochemistry 42(4): 1145-1147. 
Burbidge A. (1994) Secondary plant metabolites from tissue culture. In: In vitro cultivation of plant cells. Ed. Hunter C. F. Butterworth Heinemann, 131-151.

Caniato R., Filippini R., Cappelletti E.M. (1989) Naphthoquinone contents of cultivated drosera species Drosera binata, D. binata var. dichotoma, and D. capensis. Intern. J. Crude Drug Res. 27(3): 129-136.

Crouch I.J., Finnie J.F., van Staden J. (1990) Studies on the isolation of plumbagin from in vitro and in vivo grown Drosera species. Plant Cell Tissue Organ Cult. 21(1): 7982.

Cushnie T.P.T., Lamb A.J. (2005) Antimicrobial activity of flavonoids. Int. J. Antimicrob. Agents 26(5): 343-356.

Didry N., Dubreuil L., Trotin F., Pinkas M. (1998) Antimicrobial activity of aerial parts of Drosera peltata smith on oral bacteria. J. Ethnopharmacol. 60(1): 91-96.

Doostdar H., Burke M.D., Mayer R.T. (2000) Bioflavonoids: Selective substrates and inhibitors for cytochrome $P 450$ CYP1A and CYP1B1. Toxicology 144(1-3): 31-38.

Durga, R., Sridhar, P., Polasa, H. (1990) Effects of plumbagin on antibiotic resistance in bacteria. Indian J. Med. Res. A 91: 18-20.

Eckardt N.A. (2006) The role of flavonoids in root nodule development and auxin transport in Medicago truncatula. Plant Cell 18(7): 1539-1540.

Fast G. (1981) Orchideenkultur. E. Ulmer, Stuttgart.

Fernandez M.T., Mira M.L., Florêncio M.H., Jennings K.R. (2002) Iron and copper chelation by flavonoids: An electrospray mass spectrometry study. J. Inorg. Biochem. 92(2): 105-111.

Ferrandiz M.L., Alcaraz M.J. (1991) Anti-inflammatory activity and inhibition of arachidonic acid metabolism by flavonoids. Agents Actions 32(3-4): 283-255.

Ferreira A.C.F., Lisboa P.C., Oliveira K.J., Lima L.P., Barros I.A., Carvalho D.P. (2002) Inhibition of thyroid type 1 deiodinase activity by flavonoids. Food Chem. Toxicol. 40(7): 913-917.

Ferreira D.T., Andrei C.C., Saridakis H.O., De Jesus Faria T., Vinhato E., Carvalho K.E., Braz-Filho R. (2004) Antimicrobial activity and chemical investigation of Brazilian Drosera. Memorias do Instituto Oswaldo Cruz 99(7): 753-755.

Garnett K. (1982) Cultivation and propagation of insectivorous plants. Plant Propagators Soc. 31: 16-324.

Grevenstuk T., Coelho N., Gonçalves S., Romano A. (2010) In vitro propagation of Drosera intermedia in a single step. Biol. Plantarum 54(2): 391-394.

Grevenstuk T., Gonçalves S., Nogueira J.M.F., Bernardo-Gil M.G., Romano A. (2012) Recovery of high purity plum bagin from Drosera intermedia. Industrial Crops Prod. 35(1): 257-260.

Hahlbrock K., Lamb C.J., Purwin C., Ebel J., Fautz E., Schafer E. (1981) Rapid response of suspension-cultured parsley cells to the elicitor from Phytophthora megasperma var. sojae. Plant Physiol. 67: 768-773.

Hilton M.G., Rhodes M.J.C. (1993) Factors affecting the growth and hyoscyamine production during batch culture of transformed roots of Datura stramonium. Planta Med. 59(4): 340-344.

Hirsikorpi M., Kämäräinen T., Teeri T., Hohtola A. (2002) Agrobacterium-mediated transformation of round leaved sundew (Drosera rotundifolia L.). Plant Sci. 162(4): 537542.

Hook I.L.I. (2001) Naphthoquinone contents of in vitro cultured plants and cell suspensions of Dionaea muscipula and Drosera species. Plant Cell, Tiss. Organ Cult. 67(3): 281-285.

Iwashita K., Kobori M., Yamaki K., Tsushida T. (2000) Flavonoids inhibit cell growth and induce apoptosis in B16 melanoma $4 A 5$ cells. Biosci. Biotechnol. Biochem. 64(9): 1813-1820.

Jang G., Kim K., Park R. (2003) Micropropagation of venus fly trap by shoot culture. Plant Cell Tiss. Organ Cult. 72(1): 95-98.

Janssens J. (1986) In vitro propagation of sundew, Drosera regia Stephens. Mededelingen van de Faculteit Landbouwwetensschappen, Rijksuniversiteit Gent 51: 61-66.

Jayaram K., Prasad M.N.V. (2005) Rapidly in vitro multiplied drosera as reliable source for plumbagin bioprospection. Curr. Sci. 89(3): 447-448.

Jayaram K., Prasad M.N.V. (2006) Drosera indica L. and D. burmanii vahl., medicinally important insectivorous plants in andhra pradesh - regional threats and conservation. Curr. Sci. 91(7): 943-946.

Juniper B.E., Robins R.J., Joel D.M. (1989) The carnivorous plants. Academic Press, London.

Kämäräinen T., Uusitalo J., Jalonen J., Laine K., Hohtola A. (2003) Regional and habitat differences in 7-methyljuglone content of Finnish Drosera rotundifolia. Phytochemistry 63(3), 309-314.

Kawiak A. (2002) Zastosowanie kultur in vitro do mikropropagacji roślin owadożernych i produkcji cennych metabolitów wtórnych. Master Thesis, University of Gdańsk.

Kawiak A., Królicka A., Łojkowska E. (2002) Micropropagation of carnivorous plants for the production of secondary metabolites from the group of naphthoquinones. $29^{\text {th }}$ Ann. Conf. of the Jagiellonian University "Progress in molecular biology”, Kraków, Poland, 37.

Kawiak A., Królicka A., Lojkowska E. (2003) Direct regeneration of Drosera from leaf explants and shoot tips. Plant Cell Tiss Organ Cult. 75(2): 175-178.

Kawiak A., Królicka A., Łojkowska E. (2011) In vitro cultures of Drosera aliciae as a source of a cytotoxic naphthoquinone: ramentaceone. Biotechnol. Lett. 33(11): 23092316.

Kawiak A., Piosik J., Stasilojc G., Gwizdek-Wisniewska A., Marczak L., Stobiecki M., Lojkowska E. (2007) Induction of apoptosis by plumbagin through reactive oxygen species-mediated inhibition of topoisomerase II. Toxicol. Appl. Pharmacol. 223(3): 267-276.

Kawiak A., Zawacka-Pankau J., Wasilewska A., Stasilojc G., Bigda J., Lojkowska E. (2012a) Induction of apoptosis in HL-60 cells through the ROS-mediated mitochondrial 
pathway by ramentaceone from Drosera aliciae. J. Nat. Prod. 75(1): 9-14.

Kawiak A., Zawacka-Pankau J., Lojkowska E. (2012b) Plumbagin induces apoptosis in Her2-overexpressing breast cancer cells through the mitochondrial-mediated pathway. J. Nat. Prod. 75(4): 747-751.

Kohlmünzer S. (2003) Farmakognozja. Podręcznik dla studentów farmacji. PZWL, Warszawa.

Kołodziejski D. (2010) Porównanie efektywności wybranych technik ekstrakcji/fugowania metabolitów wtórnych z suchego materiału roślin owadożernych. Master Thesis, Gdańsk University of Technology.

Krolicka A., Szpitter A., Gilgenast E., Romanik G., Kaminski M., Lojkowska E. (2008) Stimulation of antibacterial naphthoquinones and flavonoids accumulation in carnivorous plants grown in vitro by addition of elicitors. Enzyme Microbial. Technol. 42(3): 216-221.

Krolicka A., Szpitter A., Maciag M., Biskup E., Gilgenast E., Romanik G., Kaminski M., Wegrzyn G., Lojkowska E. (2009) Antibacterial and antioxidant activity of the secondary metabolites from in vitro cultures of Drosera aliciae. Biotechnol. Appl. Biochem. 53(3): 175-184.

Krolicka A., Szpitter A., Stawujak K., Baranski R., GwizdekWisniewska A., Skrzypczak A., Kaminski M., Lojkowska E. (2010) Teratomas of Drosera capensis var. alba as a source of naphthoquinone: ramentaceone. Plant Cell Tiss. Organ. Cult. 103: 285 - 292.

Kukułczanka K., Cząstka B. (1987) Rozmnażanie rosiczek (Drosera L.) w warunkach in vitro. Wiad. Bot. 31(2): 61-64.

Kukułczanka K., Cząstka B. (1991) Rozmnażanie wybranych gatunków Droseraceae i utworzenie banku genów w kulturze in vitro. Prace Ogrodu Botanicznego PAN (1): 55-61.

Kukułczanka K, Kromer K, Klonowska B, Cząstka B (1991). Wpływ temperatury na przechowywanie kultur roślin Droseraceae in vitro. Prace Ogrodu Botanicznego PAN 1: 63-68.

Kukułczanka K., Cząstka B., Arczewska A. (1989) Regeneration from leaves of Dionaea muscipula Ellis cultured in vitro. Acta Hort., Third Symposium on Growth Regulators in Ornamental Horticulture, 5-10 September 1988, Skierniewice, Poland, 251: 155-160.

Kuo P.L., Hsu Y.L., Cho C.Y. (2006) Plumbagin induces G2-M arrest and autophagy by inhibiting the AKT/mammalian target of rapamycin pathway in breast cancer cells. Mol. Cancer Ther. 5(12): 3209-3221.

Kuo Y.H., Chang C.I., Li S.Y., Chou C.J., Chen C.F., Kuo Y.H., Lee K.H. (1997) Cytotoxic constituents from the stems of Diospyros maritima. Planta Med. 63(4): 363-365.

Lin C., Chen C., Lee H., Lin J. (2002) Prevention of cellular ROS damage by isovitexin and related flavonoids. Planta Med. 68(4): 365-367.

Lindemann E.G.P., Gunckel J.E., Davidson O.W. (1970) Meristem culture of Cattleya. Am. Orchid Soc. Bull. 39: 100127.

Marczak Ł., Kawiak A., Łojkowska E., Stobiecki M. (2005) Secondary metabolites in in vitro cultured plants of the genus Drosera. Phytochem. Anal. 16(3): 143-149.
McKay D.L., Blumberg J.B. (2002) The role of tea in human health: An update. J. Am. Coll. Nutrit. 21(1): 1-13.

Miksicek R.J. (1993) Commonly occurring plant flavonoids have estrogenic activity. Mol. Pharmacol. 44(1): 37-43.

Minocha S.C. (1985) In vitro propagation of Dionaea muscipula. HortSci. 20: 216-217.

Mira L., Fernandez M.T., Santos M., Rocha R., Florêncio M.H., Jennings K.R. (2002) Interactions of flavonoids with iron and copper ions: A mechanism for their antioxidant activity. Free Radical Res. 36(11): 1199-1208.

Murashige T., Skoog F. (1962) A revised medium for rapid growth and bioassays with tobacco tissue cultures. Physiol. Plant 15: 473-497.

Paper D.H., Karall E., Kremser M., Krenn L. (2005) Comparison of the antiinflammatory effects of Drosera rotundifolia and Drosera madagascariensis in the HEX-CAM assay. Phytother. Res. 19(4): 323-326.

Pich U., Schubert I. (1993) Midiprep method for isolation of DNA from plants with a high content of polyphenolics. Nucl. Acids Res. 21(14): 3328.

Pithayanukul P., Leanpolchareanchai J., Bavovada R. (2010) Inhibitory effect of tea polyphenols on local tissue damage induced by snake venoms. Phytother. Res. 24(suppl. 1): S56-S62.

Porter J.R. (1991) Host range and implications of plant infection by Agrobacterium rhizogenes. Critical Rev. Plant Sci. 10: 387-421.

Putalun W., Udomsin O., Yusakul G., Juengwatanatrakul T., Sakamoto S., Tanaka, H. (2010) Enhanced plumbagin production from in vitro cultures of Drosera burmanii using elicitation. Biotechnol. Lett. 32(5): 721-724.

Reinert R.A., Mohr H.C. (1967) Propagation of Cattleya by tissue cultures of lateral bud meristems. Proc. Am. Soc. Hortic. Sci. 91: 664-671.

Singleton P. (1999) Bakterie w biologii, biotechnologii i medycynie, transl. Markiewicz Z., PWN, Warszawa.

Taraszkiewicz A., Jafra S., Skrzypczak A., Kaminski M., Krolicka A. (2012) Antibacterial activity of secondary metabolites from in vitro culture of Drosera gigantea against plant patogen Pseudomonas syringae $p v$. syringae and $P$. syringae pv. morsprunorum. J. Plant Pathol. 94 (1, suppl): 63-68.

Vacin E.F., Went F.W. (1949) Some pH changes in nutrient solutions. Bot. Gaz. 110: 605-613.

Vasanthi H.R., ShriShriMal N., Das D.K. (2012) Phytochemicals from plants to combat cardiovascular disease. Curr. Med. Chem. 19(14): 2242-2251.

Verpoorte R., Van Der Hejden R., Ten Hoopen H.J.G., Memelink J. (1999) Metabolic engineering of plant secondary metabolite pathways for the production of fine chemicals. Biotechnol. Lett. 21(6): 467-479.

Vladimirov Y.A., Proskurnina E.V., Demin E.M., Matveeva N.S., Lubitskiy O.B., Novikov A.A., Kagan V.E. (2009) Dihydroquercetin (taxifolin) and other flavonoids as inhibitors of free radical formation at key stages of apoptosis. Biochem. (Moscow), 74(3): 301-307. 
Wang Y., Siemann E., Wheeler G.S., Zhu L., Gu X., Ding J. Yamamura S., Ozawa K., Ohtani K., Kasai R., Yamasaki K. (2012) Genetic variation in anti-herbivore chemical defences in an invasive plant. J. Ecology 100: 894-904.

Williams C.A., Grayer R.J. (2004) Anthocyanins and other flavonoids. Nat. Prod. Rep. 21(4): 539-573.

Williams S.E., Bennet A.B. (1982) Leaf closure in the Venus flytrap: an acid growth response. Science 218: 1120-1121. (1998) Antihistaminic flavones and aliphatic glycosides from Mentha spicata. Phytochemistry 48(1): 131-136.

Ziaratnia S.M., Kunert K.J., Lall N. (2009) Elicitation of 7-methyljuglone in Drosera capensis. South Afr. J. Bot. 75(1): 97-103. 